\section{OPEN JOURNAL SYSTEMS}

ISSN:2237-2202
Available on line at Directory of Open Access Journals

Journal of Hyperspectral Remote Sensing v.7, n.6 (2017) 357-366

www.periodicos.ufpe.br/revistas/jhrs
Journal of Hyperspectral Remote Sensing

\title{
Space-temporal evaluation of biophysical parameters in the High Ipanema watershed by remote sensing
}

\author{
José D. A. Oliveira ${ }^{*}$, Biancca C. de Medeiros ${ }^{* *}$, Jhon L. B. da Silva ${ }^{* * *}$, Geber B. de A. Moura ${ }^{* * * *}$, Frederico A. C. \\ Lins $^{* * * * *}$, Cristina R. Nascimento ${ }^{* * * * * *}$, Pabrício M. O. Lopes ${ }^{* * * * * * * *}$
}

${ }^{*}$ MSc in Agricultural Engineering - Departamento de Engenharia Agrícola, Universidade Federal Rural de Pernambuco -UFRPE. Av. D. Manoel de Medeiros, SN; Dois Irmãos, Recife, Pernambuco, Brasil; CEP: 52171-900. E-mail: josediorgenes@ gmail.com

** Doctoral student in Meteorology - Programa de Pós-Graduação em Ciências Climáticas, Universidade Federal do Rio Grane do Norte (UFRN), Natal, Rio Grane do Norte, Brasil. E-mail: biancca_medeiros@ hotmail.com

*** MSc in Agricultural Engineerin - Departamento de Engenharia Agrícola - UFRPE. E-mail: jhonlennoigt@hotmail.com

${ }^{* * * *} \mathrm{Ph}$.D. in Oceanography; Associate professor at UFRPE. E-mail: geber@ depa.ufrpe.br Master's student in Agricultural Engineerin - Departamento de Engenharia Agrícola - UFRPE. E-mail: frederico_acl@hotmail.com

${ }^{* * * * * *}$ Ph.D. in Agricultural Engineerin; Professor at UFRPE. E-mail: crisrodnas@gmail.com

${ }^{* * * * * * *}$ Ph.D. in Remote Sensing; Professor at UFRPE. E-mail: pabriciope@gmail.com

Received 13 June 2017; accepted 30 October 2017

\begin{abstract}
The High Ipanema watershed is located in a semiarid region and because of this, becomes more vulnerable and susceptible to the effects of environmental changes and the degradation process, it has serious economic and socio-environmental implications. In recent years with the advancement of remote sensing based on satellite imagery or other platforms, it has become possible to monitor different and large areas of the various biomes in the world. The objective of this study was to identify changes in the vegetation cover conditions in the Alto Ipanema watershed, using spectral analyzes of Landsat-8 OLI / TIRS satellite images, using remote sensing techniques. Landsat-8 OLI / TIRS satellite images were obtained from the United States Geological Survey USGS, on 10/12/2013, 14/01/2015 and 12/08/2016, where they were processed from ERDAS IMAGINE ${ }^{\circledR}$ software, version 9.1. The thematic maps of biophysical parameters were processed by $\mathrm{ArcGis}^{\circledR}$ 10.2.2 software. With the biophysical parameters analyzed, it was found that the northwest portion of the watershed presents a considerable area of exposed soils with indication of a high degree of susceptibility to degradation and that the biophysical parameters evaluated by the SEBAL algorithm are efficient in understanding the dynamics of spatial and temporal areas of semiarid environments.
\end{abstract}

Key words: degradation, vegetation index, semiarid, surface temperature, agrometeorology.

\section{Introduction}

The semiarid regions of northeastern Brazil in recent years show environmental changes and a delicate water aspect, a fact of great concern to the population, especially those who practice agricultural activities. This problem is associated with several factors, such as irregularities and low rainfall rates, which are characteristic for these regions. In addition, it is also important noting the long periods of drought that can cause irreversible damages in the various sectors of the semiarid (Hastenrath, 2012; Rodriguez et al., 2016).

However, the anthropological actions also stand out against the diverse uses and occupations of the soil in the semiarid, the forms of action in the majority of the sectors bring constant negative impacts. The Aspects like deforestation, forest fires and inadequate management of irrigated agriculture are adverse factors that contribute to the worsening of the environmental degradation of these regions, increasing areas of exposed soil, susceptibility to erosion and desertification (Dantas et al., 2010; Ribeiro et al., 2016).

The Caatinga is a biome exclusively characteristic of semiarid regions, this way the study of vegetal cover and its main characteristics becomes relevant. Observing the space-temporal distribution of vegetation is important for the efficient management of water resources, exceptionally in the planning of 
watershed management. Therefore, due to the frequent environmental changes in the semiarid region, we are looking for techniques that allow rapid and low-cost monitoring, aiming to mitigate the degradation and consequent desertification of the Caatinga, but the use of remote sensing from orbital images, which make possible large-scale studies at the regional and even global level, studies with this tool are quite observed in the regions of the Brazilian Northeast (Oliveira et al., 2012; Bezerra et al., 2014; Ferraz et al., 2014; Ribeiro et al., 2016; Lins et al., 2017).

With the use of remote sensing, it is possible to classify phenomena such as city growth, changes in land and occupation, changes in vegetation indexes, population statistics, and others things (Gallo and Xian, 2014).

So, the remote sensing has the capacity to identify diverse information at the surface and atmosphere interface, such as the investigation of biophysical parameters such as Normalized Difference Vegetation Index (NDVI), Soil-Adjusted Vegetation Index (SAVI), Leaf Area Index (LAI) and Surface Temperature (Ts), which are important in the detection of climatic changes, since the vegetation indexes have become a very useful alternative, exceptionally used in the characterization of cultivated areas and native vegetation (Gusmão et al., 2013; Bezerra et al., 2014).
In this context, the objective was to identify changes in the vegetation cover in the High Ipanema watershed, by means of remote sensing techniques, associated to the methodology of biophysical parameters calculations for the characterization of the vegetation of the region.

\section{Materials and methods}

The High Ipanema watershed is located in the Pernambuco's state. It covers part of the municipalities of Arcoverde and Pesqueira, located between the coordinates: $8^{\circ} 34$ ' 17 "and $8^{\circ} 18^{\prime} 11 "$ south latitude, and $37^{\circ} 1$ ' $35^{\circ}$ "and $36^{\circ} 47^{\prime} 20^{\prime}$ "west longitude. It has an area of $187.55 \mathrm{~km}^{2}$, with a perimeter of $90.25 \mathrm{~km}$. The north it limits with the Ipojuca river and to the west, with the Moxotó river (Silva Junior et al., 2011).

In relation to the vegetal condition, the hypoxerophilic Caatinga prevails, characterized by a great variation in its foliar regime during the year. According to Montenegro et al. (2002) the upper part of the watershed is partially covered by dense caatinga forest, where shallow soils predominate, with a thickness of less than $2 \mathrm{~m}$ on the slopes.

Figure 1 shows the study area with natural color image of RGB - 432 composition of Landsat 8 OLI satellite on August 12, 2016.
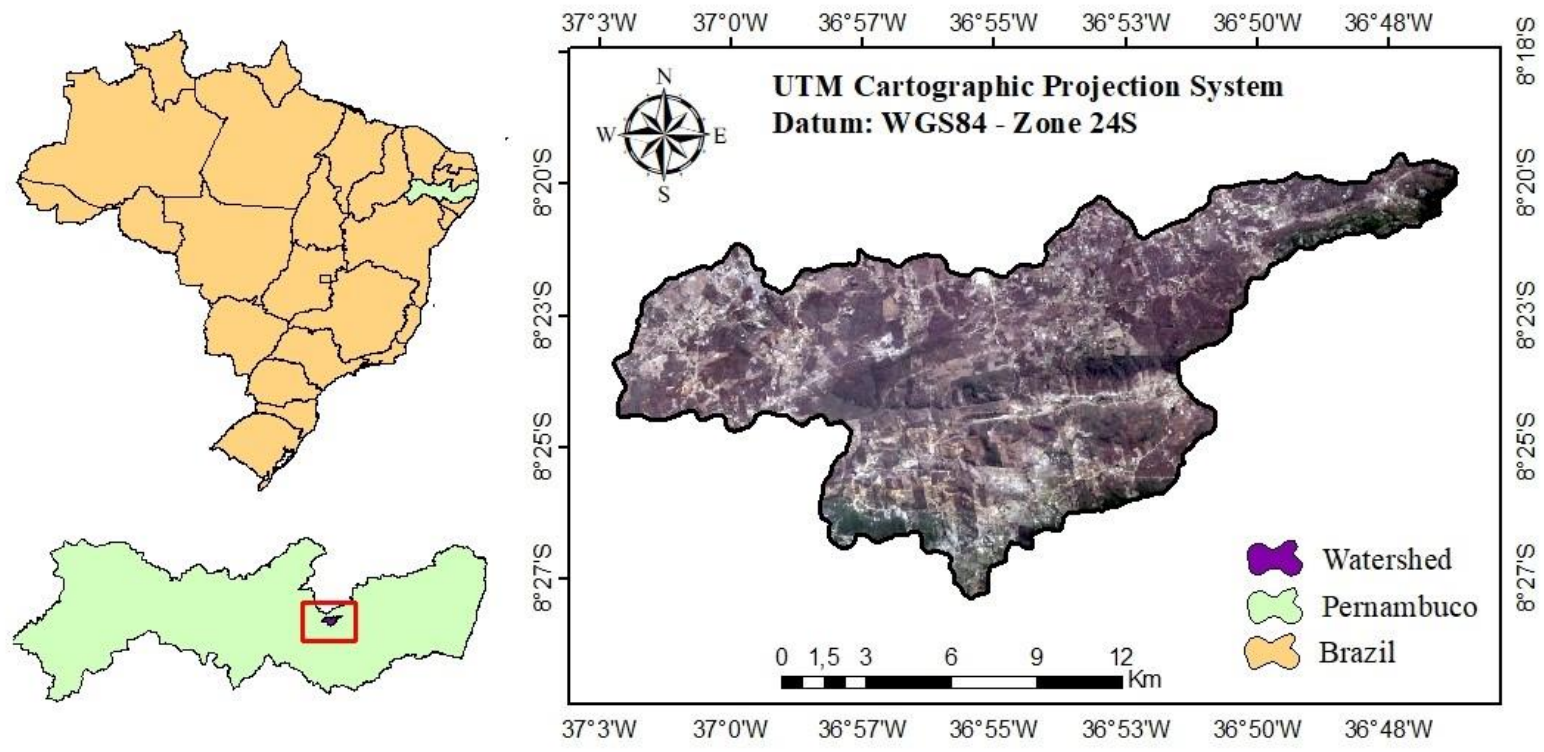

Figure 1 - Location map of High Ipanema watershed.

At first, the pre-processing of the images was done with: stacking of the bands, georeferencing of the images, and thus, the images were stacked using
ERDAS IMAGINE ${ }^{\circledR} 9.1$ tools. After preprocessing, radiance, reflectance, vegetation indexes and surface temperature were generated with the SEBAL 
algorithm, conforme Bastiaanssen et al., (1998). The thematic maps of these parameters were all processed by $\mathrm{ArcGis}{ }^{\circledR}$ 10.2.2 Software.

Spectral radiance $\left(\mathrm{L}_{\mathrm{b}}\right.$ Land 8$)$ was determined based on the additive and multiplicative terms. Radiometric radiometric coefficients were used, available in the metadata files of the images used in the research. To determine the spectral radiance in each band was used Equation 1 (Chander \& Markham, 2003; Silva et al., 2016).

$$
\mathrm{L}_{\mathrm{b} \text { Land } 8}=\operatorname{Add}_{\mathrm{rad} \mathrm{b}}+\text { Mult }_{\mathrm{rad} \mathrm{b}} \cdot \mathrm{ND}_{\mathrm{b}}
$$

Where, Addrad $\mathrm{b}$ is the additive term and Multrad $\mathrm{b}$ the multiplicative, relative to radiance, these were extracted from the metadata of each OLI image and $\mathrm{ND}_{\mathrm{b}}$ is the intensity of each pixel and band (value between 0 and 65365), which were also observed from the images under study. It was also necessary to convert the quantized and calibrated values of the gray level of each band of the OLI to the reflectance.

Thus, the radiometric coefficients related to the reflectance, made available in the metadata of the images (Chander \& Markham, 2003; Silva et al., 2016) were used. The reflectance was determined by Equation 2.

$\mathrm{r}_{\mathrm{b} \text { Land } 8}=\frac{\left(\mathrm{Add}_{\mathrm{ref} \mathrm{b}}+\text { Mult }_{\mathrm{ref} \mathrm{b}} \cdot \mathrm{ND}_{\mathrm{b}}\right)}{\cos \theta \cdot \mathrm{d}_{\mathrm{r}}}$

Where, $\mathrm{r}_{\mathrm{b} \text { Land } 8}\left(\mathrm{~W} \mathrm{~m}^{-2} \mathrm{sr}^{-1} \mu \mathrm{m}^{-1}\right)$ is the monochromatic reflectance of each pixel in each band; Addref $b$ is the term additive and Multref $b$ the multiplicative, relating to the reflectance. These were extracted from the metadata of each image used and dr obtained according to Equation 3 (Iqbal, 1983).

$\mathrm{d}_{\mathrm{r}}=1+0,033 \cdot \cos \left(\frac{\mathrm{SDY} \cdot 2 \cdot \pi}{365}\right)$

Where, DSY is the sequential day of the year and the argument of the cos function is in radians. The mean annual value of $\mathrm{dr}$ is equal to 1.00 , ranging from about 0.97 to about 1.03 . The cosine of the solar zenith angle ( $\theta$, dimensionless) is obtained from the angle of elevation of the sun (E, degrees), available in the metadata of the images, according to Equation 4.

$\cos \theta=\cos \left(\frac{\pi}{2}-E\right)=\operatorname{sen}(E)$

The NDVI was proposed by Tucker (1979), and it is an indicative of the conditions, the density and size of the vegetation, being obtained by the ratio between the difference of the reflected bands of the near infrared and of red, and the sum of the same bands, according to Equation 5 (Allen et al., 2002).

$\mathrm{NDVI}=\frac{\mathrm{r}_{\mathrm{b} \text { IR }}-\mathrm{r}_{\mathrm{b} R}}{\mathrm{r}_{\mathrm{b} \text { IR }}+\mathrm{r}_{\mathrm{b} \mathrm{R}}}$

Where, $r_{b \text { IR }}$ and $r_{b}$ R correspond respectively to the reflective bands 4 and 5 to Landsat 8 OLI.

The index of vegetation adjusted to soil conditions (SAVI), is an index that seeks to soften the antecedent effects of the soil, according to Equation 6 (Huete, 1988).

$\operatorname{SAVI}=\frac{(1+\mathrm{L}) \cdot\left(\mathrm{r}_{\mathrm{b} \text { IR }}-\mathrm{r}_{\mathrm{bR}}\right)}{\left(\mathrm{L}+\mathrm{r}_{\mathrm{b} \text { IR }}+\mathrm{r}_{\mathrm{bR}}\right)}$

Where, L is the soil adjustment constant, which depends on the soil type. For this research 0.1 was used due to the more recent studies, as proposed by (Allen et al., 2007; Silva et al., 2011).

With SAVI's data, it was possible to obtain the Leaf Area Index (LAI), defined by the ratio between the leaf area of all vegetation per unit area used by this vegetation. It is an indicator of the biomass of each pixel in the image. It was calculated according to (Allen et al., 2007), described by Equation 7, as follows:

$\mathrm{LAI}=-\frac{\ln \left(\frac{0.69-\mathrm{SAVI}}{0.59}\right)}{0.91}$

The inverted Planck equation, valid for a blackbody, was used to obtain the surface temperature. Since each pixel does not emit electromagnetic radiation as a blackbody, there is a need to introduce the emissivity of each pixel in the spectral domain of the thermal band $\varepsilon_{\mathrm{NB}}(10.4-12.5 \mu \mathrm{m})$. In turn, when emitting the long wave radiation emitted by each pixel, the emissivity in the broadband domain $\varepsilon_{0}(5-100 \mu \mathrm{m})$ must be considered.

According to Allen et al. (2002), the emissivity of each pixel $\left(\varepsilon_{\mathrm{NB}}\right)$ and a $\left(\varepsilon_{0}\right)$ can be obtained and validated, for NDVI $>0$ and $\mathrm{LAI}<3$, according to Equations 8 and 9, as follows:

$\varepsilon_{\mathrm{NB}}=0.97+0.0033 . \mathrm{LAI}$

$\varepsilon_{0}=0.95+0.01 . \mathrm{LAI}$ 
The following conditions were followed for pixels with LAI values $\geq 3, \varepsilon_{\mathrm{NB}}=\varepsilon_{0}=0.98$. For NDVI $<0, \varepsilon_{\mathrm{NB}}=0.99$ and $\varepsilon_{0}=0.985$ (Allen et al., 2002).

To obtain the surface temperature (Ts) was obtained using the spectral radiance of the thermal band $\left(\mathrm{L}_{\mathrm{b} 6}\right)$ of the satellite Landsat 5 of sensor TM and the thermal $\left(\mathrm{L}_{\mathrm{b} 10}\right)$ of the Landsat 8 of TIRS sensor and the emissivity $\left(\varepsilon_{\mathrm{NB}}\right)$ obtained in step previous. In this way, the surface temperature $(\mathrm{K})$ was obtained by the following Equation 10.

$\mathrm{T}_{\text {sup }}=\frac{\mathrm{K}_{2}}{\left(\frac{\varepsilon_{\mathrm{NB}} \cdot \mathrm{K}_{1}}{\mathrm{~L}_{\mathrm{b}}}+1\right)}$

Where, $\mathrm{K}_{1}$ and $\mathrm{K}_{2}\left(\mathrm{~W} \mathrm{~m} \mathrm{~m}^{-2} \mathrm{sr}^{-1} \mu \mathrm{m}^{-1}\right)$ are calibration constants of the Landsat $5 \mathrm{TM}$ (thermal band 6, $\mathrm{L}_{\mathrm{b} 6}, \mathrm{~K}_{1}$
$=607.76$ and $\mathrm{K}_{2}=1260.56 \mathrm{~W} \mathrm{~m}^{-1}$ ) and Landsat 8 TIRS (thermal band $10, \mathrm{~L}_{\mathrm{b} 10}, \mathrm{~K}_{1}=774.89$ and $\mathrm{K}_{2}=1321.08$ $\left.\mathrm{W} \mathrm{m} \mathrm{ms}^{-1} \mu \mathrm{m}^{-1}\right)$, extracted from the metadata of the processed images.

The estimated biophysical parameters (NDVI, SAVI, LAI and temperature) were statistically analyzed through measures of central tendency and dispersion, calculated through the ERDAS Software.

\section{Results and discussion}

Figure 2 illustrates the map of the processed images for the NDVI calculations for the periods studied, where it was divided into six classes: < 0 (Water); 0 - 0.2 (Exposed soil); 0.2-0.35 (Rala Vegetation); 0.35 - 0.5 (sparse vegetation); 0.5 - 0.65 (Transition Vegetation); > 0.65 (Dense Vegetation).

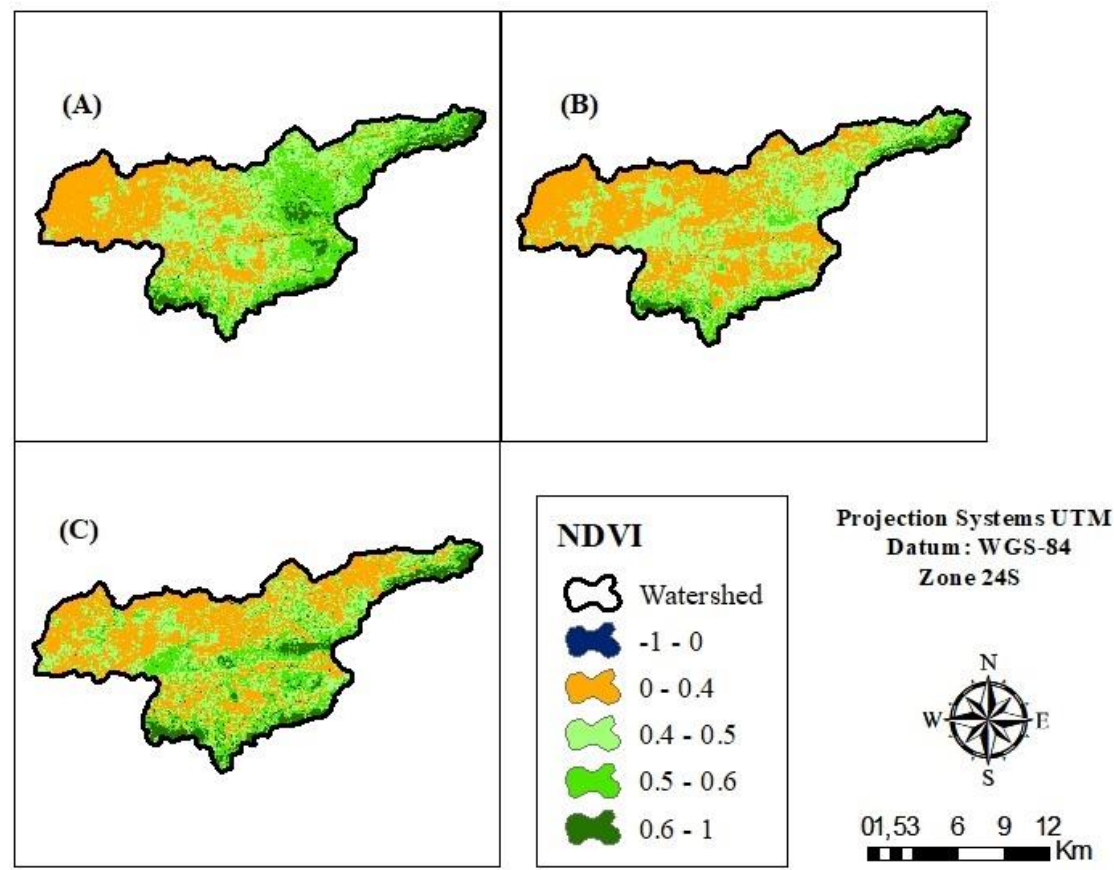

Figure 2 - Thematic map of the spatial and temporal distribution of the NDVI on the dates: 10/12/2013 (A), 14/11/2015 (B), 12/08/2016 (C).

It was contacted that in 2013 there was a smaller amount of soil exposed in the municipality in relation to the other years, and that the year 2016 was where the largest amount of exposed soil occurred and consequently the least amount of vegetation in the watershed. It was also evident that in the north-western portion the areas with a lot of exposed soil were identified and that they are very propitious to the process of environmental degradation.

NDVI was efficient to verify the vegetation behavior in the watershed and according to Aquino and Oliveira (2012) with the NDVI methodology from the
Landsat images, it was satisfactory, since it provided valuable information about the vegetation behavior between the different years and the different seasons of the year.

Santos and Galvíncio (2013) verified in areas with sparse vegetation, with a predominance of shrub caatinga, NDVI values between 0.51 and 0.70 and in areas with dense vegetation, where there is a predominance of dense caatinga, ranging from 0.71 to 0.80. Chagas et al. (2008), mapping the vegetation of the municipality of Arcoverde - PE by means of NDVI, and observed that the class of dense caatinga vegetation 
were present in areas with high altitudes presenting

Gusmão et al. (2013) found NDVI values in the anthropic areas, ranging from 0.10 to 0.30 . Freire et al. (2011), using images TM on the dates 13 and $20 / 11 / 2009$, in the orbits / points $215,216 / 65,216$, $215 / 66$, found in the soil use and cover evaluation in the Pajeú basin exposed soil with occurrence at the mouth of the Pajeú River with an average of 0.17 for NDVI. values higher than 0.7 .

Table 1 shows the NDVI values, where they ranged from a minimum of -0.61 for the image of $10 / 12 / 2013$ to a maximum of 0.84 for the same year. Gomes et al. (2012) performed thematic mapping in the Sertão do São Francisco Alagoano found NDVI values ranging from -0.99 to 0.77 for TM Landsat -5 image, on 07/07/2006.

Table 1 - Values of statistical parameters, maximum, minimum, average, median, mode, standard deviation (SD) and coefficient of variation (CV), obtained in statistical analysis of NDVI vegetation index map.

\begin{tabular}{cccccccc}
\hline \multirow{2}{*}{$\begin{array}{c}\text { Figures } \\
\text { dates }\end{array}$} & Maximum & Minimum & Average & Median & Mode & SD & CV \\
\cline { 2 - 8 } & Megetation Index - NDVI \\
\hline $10 / 12 / 2013$ & 0.84 & -0.61 & 0.358 & 0.332 & 0.298 & 0.099 & 0.27 \\
$14 / 11 / 2015$ & 0.78 & -0.58 & 0.325 & 0.305 & 0.305 & 0.088 & 0.27 \\
$12 / 08 / 2016$ & 0.79 & -0.30 & 0.425 & 0.402 & 0.372 & 0.115 & 0.27 \\
\hline
\end{tabular}

The mean values and standard deviation of the NDVI presented a small variation between scenes, highlighting 14/11/2015 with the lowest mean value $(0.325)$ and $12 / 08 / 2016$ with the highest value $(0.425)$ between the periods analyzed. The table also shows that $\mathrm{CV}$ values were the same in all scenes. Ribeiro et al. (2016), in a study of the Pajeú river, found between the mean values for NDVI the lowest value of 0.42 and the highest value 0.63 and a standard deviation of 0.36 as the highest value.

For SAVI (Figure 3), the same NDVI intervals were used. The results of the SAVI showed similarities to the results obtained with the NDVI values, but as expected, they had a higher presence in the vegetation indexes, because the "L" constant decreases the influence of the soil spectral response on the SAVI calculation.

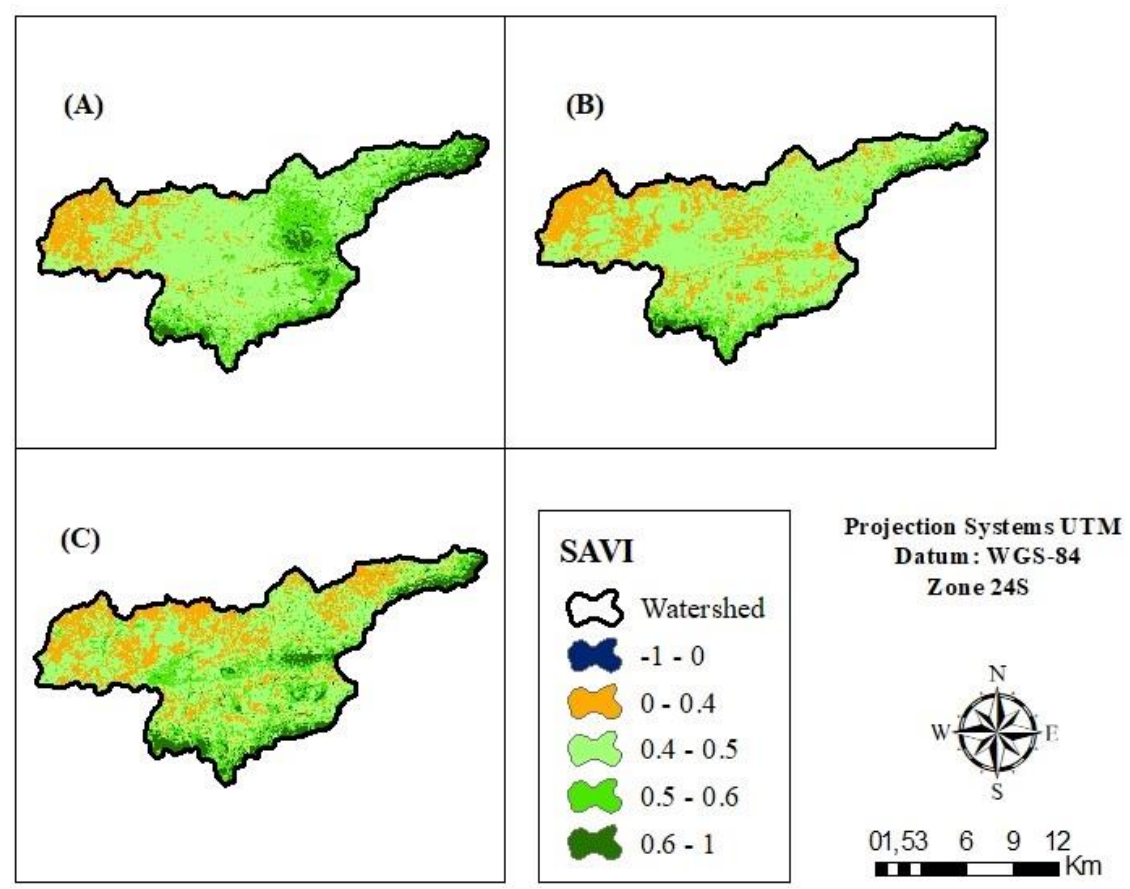

Figure 3 - Thematic map of the spatial and temporal distribution of SAVI on the dates: 10/12/2013 (A), 14/11/2015 (B), 12/08/2016 (C). 
For Almeida (2012) with the values obtained from the SAVI, it is possible to verify in a more reliable way the level of degradation of the vegetal cover in semiarid areas in view of the contribution that the factor of soil adjustment provides.

According to Braz et al. (2015), in a study on the vegetation cover dynamics in the Córrego Ribeirãozinho watershed in the municipality of Selvíria - MS, found similarities in their results for NDVI and SAVI, with SAVI showing more reliable results in the application of this study, regarding the representation of the vegetation.
Miranda and Nascimento (2013) point out that SAVI when compared to NDVI, separates soil areas from vegetation areas and ponders different weights for each of these classes, making the soil effect more evident and less expressive.

Table 2 shows the values of the statistical parameters obtained in the statistical analysis of the SAVI vegetation index. The respective maximum and minimum values ranged from 0.78 to -0.35 that was found on $10 / 12 / 2013$. The highest average value was 0.357 for the year 2016 .

Table 2 - Values of statistical parameters, maximum, minimum, average, median, mode, standard deviation (SD) and coefficient of variation (CV) obtained in the statistical analysis of SAVI vegetation index.

\begin{tabular}{cccccccc}
\hline \multirow{2}{*}{$\begin{array}{c}\text { Figures } \\
\text { dates }\end{array}$} & Maximum & Minimum & Average & Median & Mode & SD & CV \\
\cline { 2 - 8 } & Anegetation Index - SAVI \\
\hline $10 / 12 / 2013$ & 0.78 & -0.35 & 0.298 & 0.277 & 0.255 & 0.081 & 0.27 \\
$14 / 11 / 2015$ & 0.72 & -0.31 & 0.278 & 0.262 & 0.254 & 0.070 & 0.25 \\
$12 / 08 / 2016$ & 0.72 & -0.23 & 0.357 & 0.334 & 0.301 & 0.096 & 0.27 \\
\hline
\end{tabular}

Santos et al. (2015), analyzing the parameters NDVI and SAVI in an irrigated area located near the city of Paranapanema - SP, found for the SAVI the mean values of $0.48(01 / 30 / 2014)$ and 0,338 (09/09/2014), respectively.

The values of standard deviation and coefficient of variation were close. Ribeiro et al. (2016) obtained the highest value of the standard deviation (0.181) for the year 2005 and less than 0.113 in the year 2012 in the Pajeú river.

The information contained in the Figure 4 represents the result of the LAI as being a biophysical variable, defined as the leaf area density (vegetation cover). The highest LAI values

are in the presence of dark green tones in the wellvegetated areas of the basin, while the orange tone indicates very little presence of leaves and the red tone presence of water.

Souza (2014) observed the lowest values of LAI in water and exposed soil area, with the highest values being on areas with vegetation, be it herbaceous or arboreal/shrub.
As for the LAI data, the same ones when represented cartographically are largely equivalent to the data obtained by calculating the SAVI. Varying only in the division and measurement of classes by index of leaf area.

Table 3 shows the statistical parameters of LAI, where the minimum value varied from $0.10 \mathrm{~m}^{2} \mathrm{~m}^{-}$ ${ }^{2}$, and the maximum was $6 \mathrm{~m}^{2} \mathrm{~m}^{-2}$ for all years. The mean values observed were at a minimum of $0.418 \mathrm{~m}^{2}$ $\mathrm{m}^{-2}$ on November 14, 2015 and a maximum of $0.6 \mathrm{~m}^{2}$ $\mathrm{m}^{-2}$ on August 12, 2016.

Jordão et al. (2015) when analyzing the variability and spatial dependence of leaf area index (LAI) values in natural areas of 'low' field, 'high' field and transition forest in the South of Amazonas, found the average value of the area index (LAI) in the transition forest (4.42), followed by the 'high' field (2.03) and the 'low' field (1.72).

The values of standard deviation and coefficient of variation varied to the minimum in the DP value of 0.245 as of 14/11/2015 and a maximum of 0.417 as of $12 / 08 / 2016$. Souza (2014) found standard deviation ranging from 0.2 to 0.8 . 


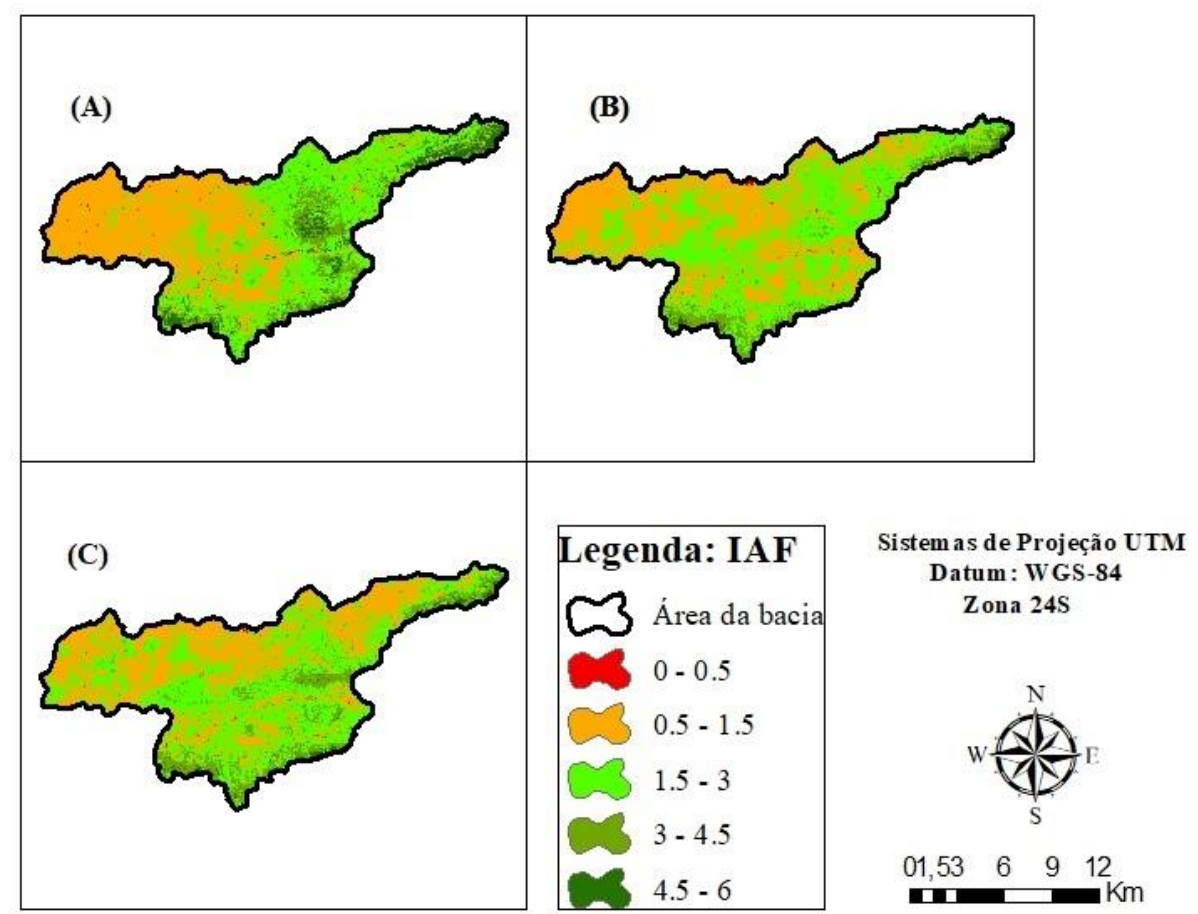

Figure 4 - Thematic map of the spatial and temporal distribution of the LAI on the dates: 10/12/2013 (A), 14/11/2015 (B), 12/08/2016 (C).

Table 3 - Values of statistical parameters, maximum, minimum, average, median, mode, standard deviation (SD) and coefficient of variation (CV) obtained in the statistical analysis of LAI vegetation index cards.

\begin{tabular}{cccccccc}
\hline \multirow{2}{*}{$\begin{array}{c}\text { Pictures } \\
\text { dates }\end{array}$} & Maximum & Minimum & Average & Median & Mode & SD & CV \\
\cline { 2 - 8 } & \multirow{2}{*}{ Andex of vegetation - LAI $\left(\mathbf{m}^{\mathbf{2}} \mathbf{~ m}^{-\mathbf{2}}\right)$} \\
\hline $10 / 12 / 2013$ & 6.00 & 0.10 & 0.484 & 0.386 & 0.315 & 0.315 & 0.65 \\
$14 / 11 / 2015$ & 6.00 & 0.10 & 0.418 & 0.339 & 0.316 & 0.245 & 0.58 \\
$12 / 08 / 2016$ & 6.00 & 0.10 & 0.694 & 0.553 & 0.410 & 0.417 & 0.60 \\
\hline
\end{tabular}

In the Figure 5 below presents the thematic map of Surface Temperature in the High Ipanema watershed, for the following dates: 10/12/2013 (A), 14/11/2015 (B) and 12/08/2016 (C). The lowest surface temperature values (15-22) were found in the water and where vegetation was present, which were represented by the blue and light green shades.
The red tonality represents the highest temperature that is found in exposed soils (37-45). Gusmão et al. (2013) obtained average temperatures lower than $21{ }^{\circ} \mathrm{C}$ in water bodies, observing, also, the same behavior for sites with the presence of the larger native vegetation along all the studied days. 


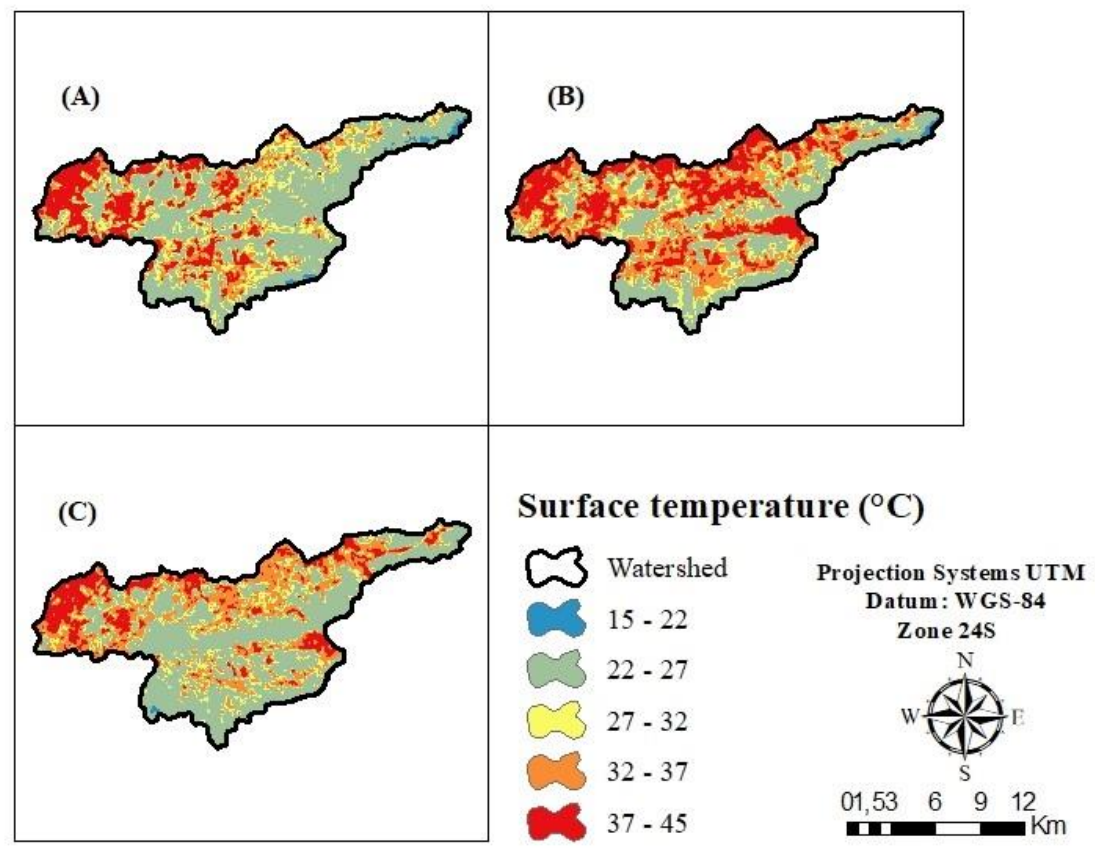

Figure 5 - Thematic map of the spatial and temporal distribution of surface temperature on the dates: 10/12/2013 (A), 14/11/2015 (B), 12/08/2016 (C).

Table 4 shows the statistical parameters obtained in the statistical analysis of Ts charts $\left({ }^{\circ} \mathrm{C}\right)$. It is observed that $\mathrm{Ts}$ had $36.5{ }^{\circ} \mathrm{C}$ as minimum temperature on $12 / 08 / 2016$ and for maximum of $47{ }^{\circ} \mathrm{C}$ on 10/12/2013. The year 2015 also had the highest average with $38.93{ }^{\circ} \mathrm{C}$.
Oliveira et al. (2012) found a sharp change in Ts class between days $10 / 7 / 1989$ and $29 / 8 / 2007$, in the values of $18-23{ }^{\circ} \mathrm{C}$ and $23-30{ }^{\circ} \mathrm{C}$, respectively, and $\mathrm{Ts}$ even higher than $30^{\circ} \mathrm{C}$ for this last day, in the urban areas of the towns at Pombos and Vitória de Santo Antão - PE.

Table 4 - Values of statistical parameters, maximum, minimum, average, median, mode, standard deviation (SD) and coefficient of variation $(\mathrm{CV})$, obtained in the statistical analysis of surface temperature $-\mathrm{T}_{\mathrm{s}}\left({ }^{\circ} \mathrm{C}\right)$.

\begin{tabular}{cccccccc}
\hline \multirow{2}{*}{ Pictures dates } & \multicolumn{7}{c}{ Temperatura da superfície $-\mathbf{T}_{\mathbf{s}}\left({ }^{\mathbf{0}} \mathbf{C}\right)$} \\
\cline { 2 - 8 } & Maximum & Minimum & Average & Median & Mode & SD & CV \\
\hline $10 / 12 / 2013$ & 47.00 & 25.26 & 35.80 & 35.93 & 36.19 & 3.031 & 0.08 \\
$14 / 11 / 2015$ & 46.90 & 27.55 & 38.93 & 39.21 & 41.02 & 3.192 & 0.08 \\
$12 / 08 / 2016$ & 36.50 & 19.60 & 28.13 & 28.25 & 28.72 & 2.991 & 0.09 \\
\hline
\end{tabular}

In general, the analyzed parameters behaved according to the results observed in the literature, showing an excellent applicability of the SEBAL to the region, through the responses of vegetation indexes and temperature, confirming the importance of these to subsidize the monitoring of natural resources quickly and efficiently.

\section{Conclusions}

The use of OLI - Landsat 8 images enabled the elaboration of maps of biophysical parameters in the
Alto Ipanema watershed in the Pernambuco's semiarid. The analysis of the parameters estimated in SEBAL has consistently allowed to conclude that in the areas, when the biophysical parameters maps are observed, there are indications of areas with exposed soil that may be in the process of degradation or already degraded, mainly the northwest part of the watershed management actions and environmental protection are necessary, avoiding evolutionary processes and that can lead to the permanent degradation of the area. 
Finally, it is concluded that the use of vegetation indexes (NDVI, SAVI and LAI) and surface temperature are important tools to identify changes in vegetation cover.

\section{Acknowledgments}

The authors thank the Federal Rural University of Pernambuco (UFRPE) and the Post-Graduate Program in Agricultural Engineering (PGEA). To the National Institute of Meteorology (INMET) for the availability of meteorological data. To CAPES for the award of the doctoral scholarship.

\section{References}

Allen, R., Tasumi, M., Trezza, R., Waters, R., Bastiaanssen, W., 2002. SEBAL: Surface Energy Balance Algorithms for Land, Idaho implementation. Waters Consulting, University of Idaho, Water Watch, Inc., Idaho. Advanced Training and Users Manual, version 1.0.

Allen, R.G., Tasumi, M., Trezza, R., 2007. SatelliteBased energy balance for mapping evapotranspiration with internalized calibration (METRIC) - Model. Journal of Irrigation and Drainage Engineering 133, 380-394.

Almeida, N.V., 2012. Ordenamento territorial geoambiental da bacia Hidrográfica do rio Taperoá/semiárido paraibano. Tese (Doutorado). Niterói, UFF.

Aquino, C.M.S., Oliveira, J.G.B., 2013. Emprego do Método de Thornthwaite \& Mather (1955) para cálculo do balanço hídrico climatológico do núcleo de degradação de São Raimundo Nonato-Piauí. Revista Brasileira de Geografia Física 6, 79-90.

Bastiaanssen, W.G.M., Menenti, M., Feddes, R.A., Holtslag, A.A.M., 1998. A remote sensing surface energy balance algorithm for land (SEBAL): 1. Formulation. Journal of Hydrology 212-213, 198212.

Bezerra, J.M., Moura, G.B.A., Silva, B.B., Lopes, P.M.O., Silva, E.F.F., 2014. Parâmetros biofísicos obtidos por sensoriamento remoto em região semiárida do estado do Rio Grande do Norte, Brasil. Revista Brasileira de Engenharia Agrícola e Ambiental 18, 73-84.

Braz, A.M., Águas, T.A., Garcia, P.H.M., 2015. Análise de índices de vegetação NDVI e SAVI e índice de área foliar (IAF) para a comparação da cobertura vegetal na bacia hidrográfica do Córrego
Ribeirãozinho, município de Selvíria - MS. Revista Percurso - NEMO Maringá 7, 5-22.

Chagas, M.G.S., Galvíncio, J.D., Mendonça Pimentel, R.M., 2008. Avaliação da dinâmica espectral da vegetação de Caatinga em Arcoverde, Pernambuco. Revista de Geografia 25, 45-60.

Chander, G., Markhan, B., 2003. Revised Landsat 5 TM radiometric calibration procedures and post calibration dynamic ranges. IEEE Transactions on Geosciences and Remote Sensing 41, 2674-2677.

Dantas, J.G., Holanda, A.C., Souto, L.S., Japiassu, A., Holanda, E.M., 2010. Estrutura do componente arbustivo/arbóreo de uma área de Caatinga situada no município de Pombal-PB. Revista Verde 5, 134142.

Ferraz, A.S., Soares, V.P., Soares, C.P.B., Ribeiro, C., Binoti, D.H.B., Leite, H.G., 2014. Estimativa do estoque de biomassa em um fragmento florestal usando imagens orbitais. Floresta e Ambiente 21, 286-296.

Gallo, K., Xian, G., 2014. Application of Spatially Gridded Temperature and Land Cover Data Sets For Urban Heat Island Analysis. Urban Climate 8, 1-10.

Gomes, H.B., Silva Junior, R.S., Pace, F.T., Lima, D.K.C., Castro, P.H., Santos, F.B., Cabral, S.L., Ferreira, R.A., 2012. Mapeamento temático da cobertura vegetal na microrregião do Sertão do São Francisco Alagoano, utilizando imagens TM Landsat 5. Revista Brasileira de Geografia Física 5, 1121-1132.

Gusmão, A.C.V.L., Silva, B.B., Montenegro, S.M.G.L., Galvíncio, J.D., Oliveira, L.M.M., 2013. Indice de vegetação e temperatura da superfície no ecótono Ilha do Bananal por sensoriamento remoto. Revista de Geografia 30, 209-225.

Hastenrath, S., 2012. Exploring the climate problems of Brazil's Nordeste: a review. Climatic Change 112, 243-251.

Huete, A.R., 1988. A soil adjusted vegetation index (SAVI). Remote Sensing of Environment 25, 295309.

Iqbal, M., 1983. An introduction to solar radiation. Academic Press., London.

Jordão, W.H.C., Zanchi, F.B., Ferreira, D.M.M., Pagani, C.H.P., Luizão, F.J., Neves, J.R.D., Duarte, M.L., 2015. Variabilidade do índice de área foliar em campos naturais e floresta de transição na região Sul do Amazonas. Revista Ambiental \& Água 10, 363-375.

Lins, F.A.C., Santos Araújo, D.C., Silva, J.L.B., Lopes, P.M.O., Oliveira, J.D.A., 2017. Estimativa de 
parâmetros biofísicos e evapotranspiração real no semiárido pernambucano utilizando sensoriamento remoto. IRRIGA 1, 64-75.

Miranda, J.R., Nascimento, C.R., 2013. Análise de índices espectrais na avaliação de terraceamento em pastagem cultivadas no norte de Minas Gerais. Revista Enciclopédia Biosfera 9, 128-141.

Montenegro, A.A., Mackay, R., Montenegro, S., 2002. Coupled unsaturated saturated modelling of salinization risk in an alluvial irrigated area of north-east Brazil. Acta Universitatis Carolinae 46, 593-597.

Oliveira, L.M.M., 2012. Estimativa da evapotranspiração real por sensoriamento remoto na Bacia do Rio Tapacurá-PE. Tese (Doutorado). Recife, UFPE.

Oliveira, L.M.M., Montenegro, S.M.G.L., Antonino, A.C.D., Silva, B.B., Machado, C.C.C., Galvíncio, J.D., 2012. Análise quantitativa de parâmetros biofísicos de bacia hidrográfica obtidos por sensoriamento remoto. Revista Pesquisa Agropecuária Brasileira 47, 1209-1217.

Ribeiro, E.P., Nóbrega, R.S., Mota Filho, F.O., Moreira, E.B.M., 2016. Estimativa dos índices de vegetação na detecção de mudanças ambientais na bacia hidrográfica do rio Pajeú. Revista Geosul 31, 59-92.

Rodriguez, R.D., Singh, V.P., Pruski, F.F., Calegario, A.T., 2016. Using entropy theory to improve the definition of homogeneous regions in the semi-arid region of Brazil. Hydrological Sciences Journal 61, 2096-2109.
Santos, A.M., Galvíncio, J.D., 2013. Mudanças climáticas e cenários de susceptibilidade ambiental à desertificação em municípios do estado de Pernambuco. Revista Eletrônica de Geografia: observatorium 5, 66-83.

Santos, J.E.O., Nicolete, D.A.P., Filgueiras, R., Leda, V.C., Zimback, C.R.L., 2015. Imagens do Landsat-8 no mapeamento de superfícies em áreas irrigada. Revista Irriga \& Inovagre 1, 30-36.

Silva Junior, V.P., Montenegro, A.A.A., Silva, T.P.N., Guerra, S., Santos, E.S., 2011. Produção de água e sedimentos em bacia representativa do semiárido pernambucano. Revista Brasileira de Engenharia Agrícola e Ambiental (Impresso) 15, 1073-1081.

Silva, B.B., Braga, A.C., Braga, C.C., 2011. Balanço de radiação no perímetro irrigado São Gonçalo - PB mediante imagens orbitais. Revista Caatinga 24, 145-152.

Silva, B.B.D., Braga, A.C., Braga, C.C., Oliveira, L. M., Montenegro, S.M., 2016. Barbosa Junior, B. Procedures for calculation of the albedo with OLILandsat 8 images: Application to the Brazilian semi-arid. Revista Brasileira de Engenharia Agrícola e Ambiental 20, 3-8.

Souza, J.F., 2014. Análise das mudanças do uso e ocupação do solo, variabilidade da temperatura e do saldo de radiação em João Pessoa - PB. Dissertação (Mestrado). João Pessoa, UFPB.

Tucker, C.J., 1979. Red and photographic infrared linear combinations for monitoring vegetation. Remote Sensing of Environment 8, 127-150. 